Imam Hidayat, Mohamad Zulman Hakim, Dirvi Surya Abbas/ Pengaruh Total Asset Turnover, Leverage Dan Profitabilitas Terhadap Financial Distress

\title{
PENGARUH TOTAL ASSET TURNOVER, LEVERAGE DAN PROFITABILITAS TERHADAP FINANCIAL DISTRESS
}

\author{
Imam Hidayat ${ }^{1}$, Petty Aprilia Sari² Mohamad Zulman Hakim³ ${ }^{3}$, Dirvi Surya Abbas ${ }^{4}$ \\ 1,3,4 Universitas Muhammadiyah Tangerang \\ ${ }^{2}$ Sekolah Tinggi Ilmu Ekonomi PPI \\ Imam_accounting@yahoo.com, pettyapriliasari@gmail.com, mohamadzulmanhakim@ymail.com, \\ abbas.dirvi@gmail.com
}

\section{ABSTRACT}

The purpose of this study was to determine the effect of total asset turnover, leverage and profitability on financial distress insub-sector companies property and real estate listed on the Indonesia Stock Exchange (IDX). The research time period used is 5 years, namely the 2015-2019 period. The population of this study includes allcompanies property and real estate listed on the Indonesia Stock Exchange (IDX) for the 2015-2019 period. The sampling technique used purposive sampling technique. Based on the predetermined criteria obtained 17 companies. The type of data used is secondary data obtained from the Indonesia Stock Exchange website. The analytical method used is panel data regression analysis. The results showed that total asset turnover had no effect on financial distress, leverage had a significant negative effect on financial distress, profitability had a positive effect on financialdistress and managerialand liquidity had no significant effect on financial distress, and total asset turnover, leverage and profitability together -the same effect on financial distress.

Keywords : financial distress, total asset turnover, leverage, profitability

\section{PENDAHULUAN}

Perkembangan ekonomi di dunia tidak lepas dari kondisi investasi disuatu negara yang dimana selalu berkaitan dengan pasar modal. Perkembangan ekonomi tentunya juga sangat dipengaruhi oleh perubahan-perubahan yang sering terjadi di dalam era globalisasi saat ini. Tidak sedikit perusahaan- perusahaan di BEI dalam perkembangan ekonominya sering mengalami naik turun yang memberikan dampak tidak menguntungkan bagi perusahaan.

Financial Distress adalah kondisi dimana perusahaan mengalami kesulitan keuangan sebelum terjadinya kebangkrutan, sehingga membuat perusahaan untuk melakukan likuiditas. Kondisi financial distress menggambarkan perusahaan yang tidak bisa mengendalikan manajemennya dan tidak bisa bersaing dengan perusahaan lainnya. Dampak yang timbul akibat terjadinya financial distress yaitu investor dan kreditur akan cenderung berhati-hati dalam melakukan investasi atau memberikan pinjaman pada perusahaan tersebut. Kreditur yang mengetahui bahwa perusahaan sedang dalam kondisi financial distress, sebaiknya tidak memberikan pinjaman karena akan sangat beresiko, kecuali manajemen perusahaan sudah mempersiapkan strategi yang tepat untuk mengatasi masalah tersebut. Untuk mengatasi masalah kesulitan keuangan seperti ini, maka perusahaan memiliki beberapa alat dan teknik dalam mengawasi kondisi keuangan perusahaan. Laporan keuangan dapat dijadikan dasar untuk 
mengukur kondisi financial distress suatu perusahaan melalui analisis laporan keuangan dengan menggunakan rasio-rasio keuangan yang ada yaitu Total Asset Turnover, Leverage dan Profitabilitas.

Ada berbagai macam cara yang bisa digunakan untuk memprediksi financial distress, seperti model analisis springate (SScore). Analisis kebangkrutan ini dikenal karena selain caranya mudah keakuratan dalam menentukan prediksi kebangkrutannya pun cukup akurat. Analisis kebangkrutan tersebut dilakukan untuk memprediksi suatu perusahaan sebagai penilaian dan pertimbangan akan suatu kondisi perusahaan (Ben, 2015).

\section{KAJIAN PUSTAKA DAN PENGEMBANGAN HIPOTESIS}

\section{Teori Sinyal}

Signaling theory merupakan teori yang menjelaskan mengenai bahwa laporan keuangan digunakan untuk memberi sinyal positive (good news) atau sinyal negative (bad news) kepada pihak eksternal. Teori sinyal sangat relevan digunakan sebagai acuan dalam penelitian ini karena sinyal-sinyal dan informasi yang beredar dapat mempengaruhi tindakan yang diambil investor. Dalam laporan tahunan terdapat informasi yang relevan dan menyajikan semua informasi yang berguna bagi pengguna laporan keuangan. Investor menggunakan laporan tahunan ini untuk melakukan kombinasi investasi dengan tetap memperhitungkan resiko yang akan terjadi. Dengan mengumumkan informasi mengenai prospek yang baik dimasa mendatang, pihak perusahaan berharap investor akan tertarik untuk menanamkan modalnya pada perusahaan.

\section{Pengaruh Total Asset Turnover Terhadap Financial Distress}

Total asset turnover yang dinilai dengan membagi penjualan dengan jumlah aktiva. Peningkatan penjualan yang relatif besar dibandingkan dengan peningkatan aktiva akan membuat rasio ini semakin tinggi, sebaliknya rasio ini akan semakin rendah jika peningkatan penjualan lebih kecil dari peningkatan aktiva.

Beberapa Penelitian terdahulu diantaranya (Widhiari \& Aryani Merkusiwati, 2015) yang menyatakan bahwa Total Asset Turnover berpengaruh negatif terhadap financial distress. Karena Semakin tinggi perputaran total aktiva maka semakin kecil kemungkinan perusahaan mengalami kondisi financial distress. Artinya jika perputaran aktiva cepat sehingga menghasilkan laba maksimal, dan pemakaian keseluruhan aktiva optimal. Hal ini berbeda dengan penelitian yang dilakukan (Nakhar Nur Aisyah, Farida Titik Kristanti, 2017),yang menunjukkan tidak adanya pengaruh antara perputaran total aktiva terhadap financial distress.

H1 : Total Asset Turnover berpengaruh terhadap financial distress

\section{Pengaruh Leverage Terhadap Financial Distress}

Rasio Leverage diperlukan untuk mengukur kemampuan perusahaan dalam membayar utang (jangka panjang dan jangka pendek). Apabila suatu perusahaan pembiayaannya lebih banyak menggunakan utang, hal ini beresiko akan terjadi kesulitan keuangan dimasa yang akan datang. Penggunaan sumber dana ini akan berakibat pada timbulnya kewajiban bagi perusahaan untuk mengembalikan dana dengan bunga yang timbul. Jika keadaan ini tidak di imbangi dengan pendapatan yang baik maka besar kemungkinan perusahaan akan 
mudah mengalami financial distress (Agusti,2013)

Beberapa penelitian terdahulu di antaranya (Purwanto, 2015), kristianti, et al (2016) menyatakan bahwa leverage berpengaruh positif terhadap financial distress. Ini berarti semakin besar kegiatan perusahaan yang dibiayai oleh hutang semakin besar kegiatan pula kemungkinan terjadinya kondisi financial distres, akibat semakin besar kewajiban perusahaan untuk membayar hutang tersebut. Hasil penelitian yang berbeda ditemukan pula oleh (Nakhar Nur Aisyah, Farida Titik Kristanti, 2017) yang menyatakan bahwa leverage tidak memiliki pengaruh terhadap financial distress

$\mathrm{H} 2$ : Leverage berpengaruh terhadap financial distress

\section{Pengaruh Profitabilitas Terhadap Financial Distress}

Profitabilitas adalah kemampuan perusahaan untuk menghasilkan laba pada periode tertentu. Perusahaan memiliki laba yang tinggi berarti kinerjanya baik dan sebaliknya . Laba perusahaan selain merupakan indikator kemampuan perusahaan memenuhi kewajiban bagi para penyandang dananya juga merupakan elemen dalam menciptakan prospek perusahaan di masa akan datang.

Menurut (Hidayat \& Meiranto, 2014) yang menunjukkan bahwa rasio keuangan profitabilitas berpengaruh signifikan terhadap financial distress. Artinya jika perusahaan menghasilkan laba yang tinggi maka perusahaan akan jauh dari ancaman kondisi financial distress. Hal ini berbeda dengan penelitian yang dilakukan oleh (Rohmadini et al., 2018) yang menyatakan bahwa profitabilitas yang di proksikan dengan return on asset (ROA) tidak memiliki pengaruh terhadap financial distress.

H3 : Profitabilitas berpengaruh terhadap financial distress

\section{METODE PENELITIAN}

Metode pengambilan sampel yang baik digunakan dalam penelitian ini adalah dengan menggunakan metode purposive sampling. Sampel dalam penelitian ini adalah Perusahaan Sektor Propery \& Real estate yang terdaftar di Bursa Efek Indonesia (BEI) periode 2015-2019 dengan metode purposive sampling terpilih 17 perusahaan yang memenuhi kriteria. Dalam penelitian ini, teknik pengumpulan data yang digunakan data yang digunakan adalah studi dokumentasi. Sumber data yang digunakan adalah publikasi laporan keuangan masingmasing perusahaan.

\section{HASIL DAN PEMBAHASAN}

Analisis data yang digunakan adalah regresi data panel dengan menggunakan software Microsoft Excel 2016 dan Eviews 9.0 untuk pengolahan data penelitian secara sistematis persamaan regresi model penelitian yang digunakan sebagai berikut :

\section{Statistik Deskriptif}

Statistik deskriptif memberikan gambaran atau deskripsi suatu data yang dilihat dari nilai ratarata (mean), median, maksimum, minimum, standard deviation, skewness, kurtosis dan jarque-bera. Hasil analisis statistik deskriptif dari keempat variabel yang digunakan dalam penelitian ini adalah sebagai berikut: 
Tabel 1 Hasil Pengujian Statistik Deskriptif

\begin{tabular}{|c|c|c|c|c|}
\hline & $F D$ & TATO: & D.15R & nOA \\
\hline Meant & a 7 tes47 & 0.58395 & 5460633 & 0050053 \\
\hline Mectar & 0.513450 & 0.965200 & 5400350 & 0025900 \\
\hline Watimum & 3844760 & 0521160 & 1.058700 & 0356000 \\
\hline Mirimite & .0373600 & 0011600 & 0.03500 & 0.105301 \\
\hline Std-Dev. & 0.705420 & 0.105775 & E.230230 & 0065259 \\
\hline Skewiness & 2297477 & 0529466 & -0059059 & 2235894 \\
\hline Kurtoeia & B.959421 & 3.375558 & 2176982 & 11.64045 \\
\hline Jasque-Bera & 200.7275 & 4.478930 & 2448509 & $3352 \overline{2469}$ \\
\hline Probatsin & 6.000050 & $0+05942$ & 0203977 & 6000060 \\
\hline $50 m$ & ब. & 15.52540 & अ.8stare & 2554500 \\
\hline Sum sq ber & 57 ह6. & 0957684 & 4452887 & $035 \% 730$ \\
\hline Observahons & 85 & DS & 55 & 85 \\
\hline
\end{tabular}

Total Asset Turnover (TATO) secara keseluruhan memiliki nilai minimum adalah 0.011600 dan nilai maksimum sebesar 0.521100 . pada rasio ini memiliki nilai rata-rata sebesar 0.183358 dengan standard deviation 0.106775 yang secara umum menunjukkan bahwa dari 17 sampel perusahaan sub sektor property dan real estate memiliki tingkat perputaran aktiva yang efektif sehingga mampu menghasilkan penjualan mencapai laba yang optimal.

Leverage dengan proksi Debt to Asset Ratio (DAR) secara keseluruhan memiliki nilai minimum adalah 0.034500 dan nilai maksimum sebesar 1.058700. Pada rasio ini memiliki nilai rata-rata sebesar 0.409633 dan nilai standard deviation 0.230238. Hal ini menunjukkan bahwa yang dari 17 sampel perusahaan yang diteliti nilai rata-rata lebih tinggi daripada nilai standar deviasi. Dengan tingginya nilai ratarata pada variabel Leverage yang diukur dengan DAR menjelaskan bahwa kemapuan perusahaan dalam melunasi kewajibannya masih rendah sehingga jika dibiarkan terus-menerus akan memungkinkan perusahaan masuk kedalam kondisi Financial Distress
Profitabilitas yang di proksikan dengan Return on Asset (ROA) secara keseluruhan memiliki nilai maksimum adalah 0.358900 dan nilai minimum -0.105500 menunjukkan bahwa ada perusahaan sampel yang mendapatkan profit negatif. Profit negatif dapat terjadi karena krisis global. Saat krisis terjadi, perusahaan melakukan strategi pemasaran agar perusahaan tetap berjalan.

Financial Distress dengan proksi Springate memiliki Nilai maksimum sebesar 3.844700 dan nilai minimum sebesar 0.373600 . Nilai rata-rata 0.716547 dengan nilai standar deviasi sebesar 0.785480, Hal ini menunjukkan bahwa nilai standar deviasi lebih tinggi daripada nilai rata-rata yang berarti sebaran data untuk Financial Distress dengan proksi springate menjelaskan bahwa perusahaan yang mengalami kesulitan keuangan pada 17 perusahaan property dan real estate yang digunakan cenderung lebih sedikit 
Imam Hidayat, Mohamad Zulman Hakim, Dirvi Surya Abbas/ Pengaruh Total Asset Turnover, Leverage Dan Profitabilitas Terhadap Financial Distress

\section{Interpretasi Hasil}

Tabel 2 Rangkuman Hasil Penelitian

\begin{tabular}{|l|c|c|c|c|}
\hline \multicolumn{1}{|c|}{ Hipotesis } & Prediksi & t-statistic & Prob & Kesimpulan \\
\hline TATO & - & -1.093326 & 0.2775 & Ditolak \\
\hline DAR & - & -2.342629 & 0.0216 & Diterima \\
\hline ROA & + & 10.74661 & 0.0000 & Diterima \\
\hline $\begin{array}{l}\text { Total } \\
\text { Observasi }\end{array}$ & \multicolumn{5}{|c|}{85} \\
\hline $\begin{array}{l}\text { Adiusted R- } \\
\text { Square }\end{array}$ & \multicolumn{5}{|c|}{0.642674} \\
\hline F-Statistic & 51.35978 \\
\hline $\begin{array}{l}\text { Prob (F- } \\
\text { Statistic) }\end{array}$ & \multicolumn{5}{|c|}{0.00000} \\
\hline
\end{tabular}

Sumber: Eviews 9.0 , data diolah (2020)

Berdasarkan pengujian variabel Total Asset Turnover, Leverage dan Profitabilitas terhadap Financial Distress diperoleh hasil FStatistic (51.35978) > F-tabel 2.72 dan nilai Prob (f-statistic) $0.000000<0.05$, hal ini menunjukkan bahwa model regresi ini dapat digunakan untuk memprediksi Financial Distress perusahaan. Maka dapat disimpulkan bahwa Model dalam penelitian ini layak untuk digunakan.

Selain itu, penelitian ini memiliki nilai Adjusted R-Squared sebesar 0.642674 hal tersebut juga menunjukkan bahwa Financial Distress dipengaruhi oleh Total Asset Turnover, Leverage dan Profitabilitas sebesar 64.27\% sedangkan sisanya sebesar $35.73 \%$ dipengaruhi oleh faktor lain yang tidak diteliti dalam penelitian ini.

\section{Pengaruh Total Asset Turnover terhadap Financial Distress}

Berdasarkan tabel 4.26 variabel Total Asset Turnover memiliki nilai t-statistic sebesar
- 1.093326 dan nilai prob sebesar 0.2775 lebih besar dari taraf signifikansi 0.05 , maka dapat disimpulkan bahwa Total Asset Turnover (TATO) tidak memiliki pengaruh terhadap Financial Distress. Karena Financial Distress perusahaan tidak hanya disebabkan oleh tingkat penjualan yang tinggi ataupun rendah, akan tetapi terdapat aspek-asepk lain yang mempengaruhi seperti kekurangan modal, tingkat likuiditas serta terlalu besar beban hutang yang dimiliki. Setiap aspek mempunyai keterkaitan satu dengan yang lain untuk itu perusahaan harus memperhatikan aspek-aspek tersebut agar dapat terhindar dari resiko terjadinya Financial Distress.

Penelitian ini konsisten dengan penelitian yang dilakukan oleh (Nakhar Nur Aisyah, Farida Titik Kristanti, 2017) yang menunjukkan bahwa Total Asset Turnover (TATO) tidak memiliki pengaruh signifikan dan tidak dapat memprediksi Financial Distress. Hal ini tidak sejalan dengan penelitian yang 
Imam Hidayat, Mohamad Zulman Hakim, Dirvi Surya Abbas/ Pengaruh Total Asset Turnover, Leverage Dan Profitabilitas Terhadap Financial Distress

dilakukan oleh (Noviandri, 2014) yang mengatakan bahwa Total Asset Turnover berpengaruh terhadap Financial Distress.

\section{Pengaruh Leverage terhadap Financial Distress}

Berdasarkan tabel 4.26 variabel Leverage (DAR) memiliki nilai t-statistic sebesar -2.342629 dan nilai prob sebesar 0.0216 lebih kecil dari taraf signifikansi 0.05, maka dapat disimpulkan bahwa variabel Leverage (DAR) berpengaruh negatif terhadap Financial Distress. Sehingga H2 diterima, bahwa Leverage berpengaruh negatif terhadap Financial Distress. Yang artinya bahwa nilai DAR yang selalu tinggi tidak selalu memiliki probabilitas kebangkrutan yang tinggi juga tetapi juga rendah. Karena banyaknya hutang yang dimiliki perusahaan untuk menjalankan bisnis tidak berarti perusahaan semakin berada dalam kondisi financial distress

Hasil penelitian ini sejalan dengan penelitian yang dilakukan oleh (Handaru \& Mardiyati, 2014) dan (Farida Titik dan Muslih, 2018) yang mengatakan bahwa Leverage berpengaruh terhadap financial distress. Hal ini tidak sejalan dengan penelitian yang dilakukan oleh Putri dan Merkusiwati (2014) yang mengatakan bahwa Leverage tidak berpengaruh terhadap financial distress.

\section{Pengaruh Profitabilitas terhadap Financial Distress}

Berdasarkan tabel 4.26 variabel Return on Asset (ROA) menunjukkan nilai t-statistic 10.74661 lebih besar dari nilai t-tabel sebesar 1.98969 dan nilai signifikansi sebesar 0.0000 yang berarti lebih kecil dari taraf signifikansi 0.05 . Hal ini menunjukkan bahwa variabel Profitabilitas berpengaruh positif dan signifikan terhadap Financial Distress. Sehingga H3 diterima, bahwa Profitabilitas (ROA) berpengaruh positif signifikan terhadap Financial Distress.

Yang artinya ketika perusahaan mampu menghasilkan laba dengan baik maka kemungkinan perusahaan mengalami kemungkinan Financial Distress akan rendah. Maka jika perusahaan memperoleh laba yang besar akan membuat calon investor percaya untuk menanamkan modal nya diperusahaan tersebut. Hasil penelitian ini konsisten dengan penelitian yang dilakukan oleh Ramadani, et al. (2014) yang menunjukkan bahwa profitabilitas memiliki pengaruh terhadap Financial Distress.

\section{KESIMPULAN}

Pertama, Total Asset Turnover dalam penelitian ini tidak berpengaruh terhadap Financial Distress. Berdasarkan analisa peneliti, hal ini disebabkan bahwa setiap nilai TATO perusahaan property dan real estate selama periode penelitian tidak ada perubahan yang mencolok. Sehingga tidak adanya fluktuasi yang dapat mempengaruhi Financial Distress dari tahun ke tahun. Oleh karena itu, tinggi rendahnya Total Asset Turnover tidak ada pengaruhnya terhadap kondisi Financial Distress. Kedua, Leverage dalam penelitian ini berpengaruh negatif terhadap Financial Distress. Hal ini disebabkan Leverage yang diukur dengan debt to assets ratio menunjukkan apabila nilai utang terhadap aset yang dimiliki perusahaan semakin tinggi maka probabilitas perusahaan tersebut mengalami financial distress akan semakin semakin rendah.dan ketiga, Profitabilitas dalam penelitian ini berpengaruh terhadap Financial Distress. Berdasarkan analisa peneliti, hal ini disebabkan ketika perusahaan mampu menghasilkan laba dengan baik maka perusahaan akan terhindar dari kondisi Financial Distress. Periode 
penelitian hanya 5 (Lima) tahun 2015-2019, Sampel penelitian yang digunakan hanya sebatas perusahaan sub sektor sektor property dan real estate yang terdaftar di Bursa Efek Indonesia (BEI) dan Penelitian ini terbatas pada variabel yang digunakan yaitu hanya Total Asset Turnover, Leverage dan Profitabilitas dalam memprediksi Financial Distress. Pada penelitian ini menjelaskan bahwa hasil penelitian dan keterbatasan penelitian, maka rekomendasi yang dapat diberikan kepada pengembangan penelitian selanjutnya adalah bagi perusahaan, Bagi peneliti selanjutnya.

\section{DAFTAR PUSTAKA}

Almilia, L. S., \& Kristijadi, K. (2003). Analisis Rasio Keuangan Untuk Memprediksi Kondisi Financial Distress Perusahaan Manufaktur Yang Terdaftar Di Bursa Efek Jakarta. Jurnal Akuntansi Dan Auditing Indonesia, 7(2),183210.http://www.jurnal.uii.ac.id/index.p hp/JAAI/article/view/846

Ardiyanto, F. D., \& Prasetiono. (2011). Prediksi Rasio Keuangan terhadap Kondisi Financial Distress Perusahaan Manufaktur yang Terdaftar di BEI. Jurnal Dinamika Ekonomi Dan Bisnis, 8(1), 1-14.

yu, A. S. (2015). Pengaruh Likuditas, Leverage , Profitabilitas , Dan Ukuran Perusahaan Terhadap Financial Distress Studi pada Perusahaan Manufaktur Sektor Industri Dasar dan Kimia yang Terdaftar di Bursa Efek Indonesia tahun 2012-2015 ). 43(1), 138-147.

Ben, D. (2015). Analisis Metode Springate (S$\begin{array}{lr}\text { Score) Sebagai } & \text { Alat Untuk } \\ \text { Memprediksi } & \text { Kebangkrutan }\end{array}$
Perusahaan (Studi pada Perusahaan Property dan Real estate yang listing di Bursa Efek Indonesia pada Tahun 2011-2013). Jurnal Administrasi Bisnis S1 Universitas Brawijaya, 21(1),85770.

Brahmana, R. K. (2007). Identifying Financial Distress Condition in Indonesia Manufacture Industry. Journal Business, 1- 19.

Cinantya, I., \& Merkusiwati, N. (2015). Pengaruh Corporate Governance, Financial Indicators, Dan Ukuran Perusahaan Pada Financial Distress. E-Jurnal Akuntansi, 10(3), 897-915.

Farida Titik dan Muslih, M. S. H. R. D. K. (2018). Pengaruh Rasio Keuangan dan Ukuran Perusahaan Terhadap Kondisi Kesulitan Keuangan (Financial Distress) E-Proceeding of Management ISSN : 2355-9357, 5(1), 796-802.

Fitriyah, I., \& Hariyati. (2013). Pengaruh Rasio Keuangan Terhadap Financial Distress Pada Perusahaan Properti Dan Real Estate. Jurnal Ilmu Manajemen, 1(3), 760-773.

Handaru, A., \& Mardiyati, U. (2014). Jurnal Dinamika Manajemen. Jdm, 5(2), 171182.

Hanifah. (2013). Pengaruh Struktur Corporate Governance Dan Financial Indicators Terhadap Kondisi Financial Distress ( Studi Pada Perusahaan Manufaktur yang Terdaftar di Bursa. Diponegoro Journal of Accounting, 2, 1-15. 
Hidayat, M. A., \& Meiranto, W. (2014). Prediksi Financial Distress Perusahaan Manufaktur Di Indonesia, 3(3), 538-548.

Kasmir. (2012). Analisis Laporan Keuangan. PT. Raja Grafindo Persada.

Kasmir. (2014). Analisis laporan keuangan (pertama). PT. Rajagrafindo Persada.

Nakhar Nur Aisyah, Farida Titik Kristanti, D. Z. (2017). Pengaruh Rasio Likuiditas, Rasio Aktivitas, Rasio Profitabilitas, dan Rasio Leverage Terhadap Financial Distress. E-Proceeding of Management Volume 4 Nomor 1 ISSN: $\quad 2355-9357, \quad 4(1), 411-419$.

Noviandri, T. I. O. (2014). Peranan analisis rasio keuangan dalam memprediksi kondisi. 2.

Pertiwi, D. A. (2018). Pengaruh Rasio Keuangan, Growth, Ukuran Perusahaan, dan Inflasi Terhadap Financial Distress di Sektor Pertambangan Yang Terdaftar DI Bursa Efek Indonesia (BEI) Periode 2012- 2016. Jurnal Ilmu Manajemen (JIM), 6(3)

Purwanto, H. I. dan. (2015). Analisis Rasio Keuangan sebagai Alat Prediksi Financial Distress Bagi Perusahaan Manufaktur di Bursa Efek Indonesia Tahun 2009-2012. 3 Nomor 2(Fakultas Ekonomi Universitas Negri Semarang ISSN: 2086-0668), Halaman 101-109.

Renty Rismawanti, Edi Sukarmanto, \& Nurhayati. (2017). Pengaruh Likuiditas, Sales Growth dan Leverage dalam Memprediksi Kondisi Financial Distress. National and International
Scientific Journal of Unisba, 3(Financial Distress), 1-7.

Rohmadini, A., Saifi, M., \& Darmawan, A. (2018). Pengaruh Profitabilitas, Likuiditas dan Leverage Terhadap Financial Distress (Studi Pada

Perusahaan Food \& Beverage Yang Terdaftar Di Bursa Efek Indonesia Periode 2013-2016). Jurnal Administrasi Bisnis, 61(2), 11-19.

Srikalimah. (2017). Jurnal Akuntansi \& Ekonomi Fe. Un Pgri Kediri Vol. 2 No. 1, Maret 2017. 2(1), 43-66.

Sugiyono. (2016). Metode Penelitian Kuantitatif, kualitatif dan R\&D. PT. Alfabet.

Widhiari, N., \& Aryani Merkusiwati, N. (2015). Pengaruh Rasio Likuiditas, Leverage, Operating Capacity, Dan Sales Growth Terhadap Financial Distress. E- Jurnal Akuntansi, 11(2), 456- 469.

Wulandari, W., \& Musdholifah, M. (2019). Pengaruh, Studi Governance, Corporate Dan, Likuiditas Terhadap, Profitabilitas Distress, Financial Perusahaan, Pada. Jurnal Ilmu Manajemen Volume 7 Nomor 4 Jurusan Manajemen Fakultas Ekonomi Universitas Negeri Surabaya, 7, 11041117. 